\title{
BIBLIOGRAPHIES
}

\section{Whitman as Poetic Subject: Additional Citations}

In 1980 the Walt Whitman Review published a bibliography of "Whitman as Poetic Subject," compiled by Roberts W. French. French listed forty-two poems in which Whitman appears either by name or by clear allusion. A year later, Walt Whitman: The Measure of His Song appeared, edited by Jim Perlman, Ed Folsom, and Dan Campion (Minneapolis: Holy Cow! Press, 1981); Folsom's bibliography in that book (pp. 359-381) lists around three hundred poems in which Whitman appears. I offer this bibliography in the same spirit as my predecessors-one more step in the ongoing process of compiling a comprehensive list of poems about Whitman.

Samuel I. Bellman, "Whitman's Learned Astronomer (ToHimself)," Satire Newsletter 9 (1972), 163.

G. K. Chesterton, "After Walt Whitman," The New Oxford Book of English Light Verse, comp. Kingsley Amis (New York: Oxford University Press, 1978), 203.

Naomi Clark, "Late Spring, Sur Coast," California Bicentennial Poets Anthology, ed. A. D. Winans (San Francisco: Second Coming, 1976), 29.

Edwin Denby, "The grand republic's poet is," An Anthology of New York Poets, ed. Ron Padgett and David Shapiro (New York: Random House, 1970), 520.

Margarette Bell Dickson, "The Gray Poet," Literary Digest 5 (March 1927), 32.

John Ditsky, "Whitman Supra Emerson," Portland Review 28 (1982), 15.

Robert Duncan, "The Dance," The New American Poetry, ed. Donald M. Allen (New York: Grove Press, 1960), 46-47.

Gary Eddy, "Fishing with Buddies," Wetting Our Lines Together: An Anthology of Recent North American Fishing Poems, ed. Allen Hoey, with Cynthia Hoey and Daniel J. Moriarty (Syracuse: Tamarack, 1982), 30.

Andrew Glaze, "Whitman Saw It Crazily Shining," Poetry Northwest 15 (1974), 34.

John Judson, "Whitman Again," Ohio Review 16 (1975), 105.

Gertrude May Lutz, "To Walt Whitman," Prize Monologues Awarded by the San Francisco Browning Society (1945-1955) (Mill Valley: Wings, 1956), 43-44.

Tom MacInnes, "To Walt Whitman," Canadian Poetry in English, ed. Bliss Carmen and others (Westport: Greenwood, 1976), 142-144.

Christopher Morley, "Rude Brief Recitatives: For Whitman's 134th Birthday," Saturday Review of Literature (22 August 1953), 30. 
Howard Nemorov, "Strange Metamorphosis of Poets," The Western Approaches (Chicago: University of Chicago Press, 1975), 6.

Paul Potts, "I have waited to ask you this," Commentary (November 1958), 410.

J. K. Stephen, "Sincere Flattery," The New Oxford Book of English Light Verse, 175. "Walt and Watts. (An Explanation)," Critic 7 (May 1982), 268.

Southwest Missouri State University

EDWARD A. MALONE

\section{The Poets Continue to Respond: More Citations of Whitman as Poetic Subject}

As Edward Malone's preceding list suggests, there is no end to the poems that deal in some essential way with Whitman. In my lengthy list, "The Poets Respond: A Bibliographic Chronology" (in Walt Whitman: The Measure of His Song), I attempted to trace the century-old tradition of poets who talked back to Whitman in their own poems or essays. Since that list was published, I have found many more poems and essays that should be included-some that I overlooked, some that have appeared recently. I have, however, given up on trying to make an exhaustive bibliography: new poems about Whitman are appearing all the time, and old ones from many languages keep turning up. The following list contains what seem to me the most significant poems to and about Whitman that were not included in my original bibliography. There are about two hundred additional poems here; it can serve to supplement and amplify Malone's list, and perhaps to inspire others to keep searching for poems that insist on Whitman's continuing presence. I would like to thank Jim Perlman, co-editor of Measure of His Song, for his help in identifying several of these poems.

B. Alkvit-Blum, "Dayne grozn" ["Your Grasses"], Lider (New York: CYCO, 1964), 77. [Yiddish. For citations of Yiddish poems to or about Whitman in addition to those listed here-including poems by Isaac Ronch, Chaim Schwartz, and Z. Weinper-see Leonard Prager, "Walt Whitman in Yiddish," WWQR 1 (December 1983), 22-35, and Aaron Kramer, "1881: Whitman's Impact on American Jewish Poetry," cited below.]

Barbara Anderson, "There and Here," Iowa Review 12 (Spring/Summer 1981), 1-2.

Antler, "Factory," "Whitmansexual," Last Words (New York: Available Press, 1986), 41-86, 163.

Willis Barnstone, "Walter Whitman," "Jiang Yuying, Famous Professor at Beijing University, Who Daringly Rendered into Chinese the First Complete Walt Whitman," 5 A.M. in Beijing (Riverdale-on-Hudson, NY: Sheep Meadow Press, 1987), $10,66-67$.

Robert Bly, "Whitman's Line as a Public Form," Selected Poems (New York: Harper and Row, 1986), 194-198. [Essay.] 